\title{
Ilamycin C induces apoptosis and inhibits migration and invasion in triple-negative breast cancer by suppressing IL-6/STAT3 pathway
}

Qing Xie ${ }^{1 \dagger}$, Zhijie Yang ${ }^{2 \dagger}$, Xuanmei Huang ${ }^{1}$, Zikang Zhang ${ }^{1}$, Jiangbin $\mathrm{Li}^{1}$, Jianhua Ju ${ }^{2^{*}}$, Hua Zhang ${ }^{1^{*}}$ and Junying $\mathrm{Ma}^{2^{*}}$

\begin{abstract}
Background: Triple-negative breast cancer (TNBC) is the most aggressive subtype of breast cancer with poor prognosis, and its treatment remains a challenge due to few targeted medicines and high risk of relapse, metastasis, and drug resistance. Thus, more effective drugs and new regimens for the therapy of TNBC are urgently needed. Ilamycins are a kind of cyclic peptides and produced by Streptomyces atratus and Streptomyces islandicus with effective anti-tuberculosis activity. Ilamycin C is a novel compound isolated from the deep South China Seaderived Streptomyces atratus SCSIO ZH16 and exhibited a strong cytotoxic activity against several cancers including breast cancer cell line MCF7. However, the cytotoxic activity of llamycin C to TNBC cells and a detailed antitumor mechanism have not been reported.
\end{abstract}

Methods: CCK-8 assays were used to examine cell viability and cytotoxic activity of llamycin C to TNBC, non-TNBC MCF7, and nonmalignant MCF10A cells. EdU assays and flow cytometry were performed to assess cell proliferation and cell apoptosis. Transwell migration and Matrigel invasion assays were utilized to assess the migratory and invading capacity of TNBC cells following the treatment of llamycin C. The expressions of proteins were detected by western blot.

Results: In this study, we found that llamycin C has more preferential cytotoxicity in TNBC cells than non-TNBC MCF7 and nonmalignant MCF10A cells. Notably, our studies revealed the mechanism that llamycin C can induce Bax/BCl-2-related caspase-dependent apoptosis and inhibit migration and invasion through MMP2/MMP9/vimentin/ fascin in TNBC by suppressing IL-6-induced STAT3 phosphorylation.

Conclusions: This study provides the first evidence that llamycin C has significant implications for the potential as a novel IL-6/STAT3 inhibitor for TNBC treatment in the future.

Keywords: Ilamycin C, Triple-negative breast cancer, Apoptosis, Invasion, Migration, IL-6, STAT3

\footnotetext{
* Correspondence: jju@scsio.ac.cn; huazhang@gdmu.edu.cn;

majunying@scsio.ac.cn

${ }^{\dagger}$ Qing Xie and Zhijie Yang contributed equally to this work.

${ }^{2}$ CAS Key Laboratory of Tropical Marine Bio-Resources and Ecology,

Guangdong Key Laboratory of Marine Materia Medica, RNAM Center for

Marine Microbiology, South China Sea Institute of Oceanology, Chinese

Academy of Sciences, Guangzhou 510301, China

'Department of Clinical Biochemistry, Institute of Clinical Laboratory

Medicine, Guangdong Provincial Key Laboratory of Medical Molecular

Diagnostics, Guangdong Medical University, Dongguan 523808, China
}

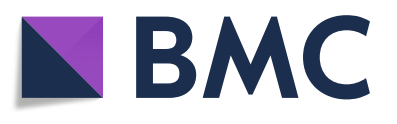

(c) The Author(s). 2019 Open Access This article is distributed under the terms of the Creative Commons Attribution 4.0 International License (http://creativecommons.org/licenses/by/4.0/), which permits unrestricted use, distribution, and

reproduction in any medium, provided you give appropriate credit to the original author(s) and the source, provide a link to the Creative Commons license, and indicate if changes were made. The Creative Commons Public Domain Dedication waiver (http://creativecommons.org/publicdomain/zero/1.0/) applies to the data made available in this article, unless otherwise stated. 


\section{Background}

Triple-negative breast cancer (TNBC) is characterized by lack of progesterone receptor (PR), estrogen receptor (ER), and human epidermal growth factor receptor 2 (HER2), accounting for about 15-20\% of all breast cancer [1]. Clinically, TNBC is more aggressive and less sensitive to typical therapies and ultimately has a higher rate of relapse and metastasis and poorer prognosis compared with other subtypes of breast cancer [2, 3]. Chemotherapy is the main treatment of TNBC, but chemotherapy resistance has become an inevitable problem [4]. Lack of well-defined molecular targets makes it a challenge to treat and improve the 5-year survival rate of patients with TNBC $[5,6]$. Therefore, new regimens including drug development based on molecular targets or chimeric antigen receptor (CAR)-engineered $\mathrm{T}$ cell approach for the treatment of TNBC are urgently needed [7].

Signal transducer and activator of transcription-3 (STAT3) is continually activated in many human cancers [8]. It can be directly or indirectly activated by many elements, such as growth factors (PDGFR, EGFR, and HER2), cytokines (IFN- $\alpha$, IL-6), and non-receptor tyrosine kinases (Src and Janus kinase family proteins) [911]. Among the Janus kinase (JAK) family, JAK2 can be activated by IL-6 and further recruits and phosphorylates STAT3, thus functioning as an intermediary between IL-6 and STAT3 [10]. Studies showed that activity of STAT3 is closely relevant to cancer progression including proliferation, apoptosis, and metastasis [12-16]. It has also been found that the abnormal activity of IL6/STAT3 relates to poor prognosis and a low survival rate in TNBC; thus, effective STAT3 inhibitors have become promising candidate drugs for treatment of it [17]. Currently, marine-derived natural products have attracted great interest for their novel structure, diverse bioactivities, and new function mechanisms; therefore, it has become a treasure of leading compounds for the development of new drugs $[18,19]$. The fact that more antitumor drugs approved by the FDA and many antitumor compounds entering preclinical and clinical research are derived from marine organisms has highlighted that natural products from marine organisms have provided a constant source for new drug discovery against cancers [20].

Ilamycins are a kind of cyclic peptides and produced by Streptomyces atratus and Streptomyces islandicus with an effective anti-tuberculosis activity [21]. Our previous study found that Ilamycin $C$ (Additional file 1: Figure S1), a novel compound isolated from the deep South China Sea-derived Streptomyces atratus SCSIO ZH16, exhibited a strong cytotoxic activity against several cancers including non-TNBC cell line MCF7 [21]. However, the cytotoxic activity to TNBC cells and detailed antitumor mechanism are still unknown. In this work, the cytotoxicity and function of Ilamycin $\mathrm{C}$ in TNBC cells were investigated and its antitumor mechanism was further explored.

\section{Methods \\ Compounds}

The structural elucidation, biosynthesis, and purification method of Ilamycin $C$ were described in our previous study [21]. The purity of Ilamycin $C$ is $97.8 \%$ analyzed by HPLC (high-performance liquid chromatography) analysis, and it was dissolved in dimethyl sulfoxide (DMSO) (Sigma). Doxorubicin and cisplatin were purchased from Sigma.

\section{Cell culture}

MDA-MB-231, BT-549, MCF7, and MCF10A cell lines were obtained from American Type Culture Collection (ATCC). All these cells were cultured according to ATCC recommendations.

\section{Cell infection with lentivirus}

The lentivirus vector was purchased from GenePharma. All vectors were verified by DNA sequencing. The lentivirus-STAT3 (LV-STAT3) or lentivirus-negative control (LV-NC) was used to infect MDA-MB-231 and BT549. After $72 \mathrm{~h}$, cells were selected using $0.6 \mu \mathrm{g} / \mathrm{ml}$ puromycin-resistant culture (Sigma) for a week. Cells were collected, and the STAT3 expression was analyzed by quantitative polymerase chain reaction (qRT-PCR).

\section{Cell transfection with RNA interference}

For STAT3 RNA interference (RNAi), siRNA duplexes (5'-CCAACGACCUGCAGCAAUA-3') against STAT3 (si-STAT3) and control duplex (5'-CCUACGCCACCAAUUUCGU-3') were purchased from GenePharma and transfected into the MDA-MB-231 and BT-549 using the Lipofectamine 3000 (Invitrogen) according to the manufacturer's guidelines.

\section{Cell viability and proliferation assays}

Cell viability was tested by Cell Counting Kit-8 (CCK-8, DojinDo). Cells were seeded at 3000 cells per well in 96well plates in triplicate and cultured for $24 \mathrm{~h}$; Ilamycin C was added for $48 \mathrm{~h}$. All control groups contained $0.1 \%$ DMSO. Then, $10 \mu \mathrm{L}$ CCK- 8 was added to every well, and plates were incubated at $37^{\circ} \mathrm{C}$ for $2-3 \mathrm{~h}$. The absorbance was detected at $450 \mathrm{~nm}$ in a Spectra Max 190 Enzyme standard instrument (Molecular Devices). Cell proliferation was measured with Click-iT ${ }^{\oplus}$ EdU Flow $\mathrm{Cy}-$ tometry Assay Kits (Invitrogen). 


\section{Apoptotic assays}

$2.0 \times 10^{5}$ cells were seeded per well in six-well plates for $24 \mathrm{~h}$, then treated with different concentrations of Ilamycin $\mathrm{C}$ for 12 or $24 \mathrm{~h}$. After this, cells were stained with Annexin V-FITC and PI or Annexin V-APC and 7-AAD at room temperature for $15 \mathrm{~min}$ and then analyzed by flow cytometry (Becton Dickinson Company).

\section{Transwell assays}

After treatment with Ilamycin C for $24 \mathrm{~h}$, cells $\left(2.0 \times 10^{5}\right.$ per well) were resuspended with serum-free medium and seeded on the top side of the filters with $8-\mu \mathrm{m}$ pore size (Millipore) and the low side was added with 10\% FBS medium. Only invasion assays need to be precoated with Matrigel. Transwell migration and invasion assays were performed according to the manufacturer's instructions. The images were taken by an inverted microscope (Olympus).

\section{Western blot analysis}

Cells were treated with different concentrations of Ilamycin $\mathrm{C}$ for $24 \mathrm{~h}$. Total proteins were obtained after the disposition of cells with RIPA lysis buffer together with protease inhibitors, phosphatase inhibitors, and PMSF

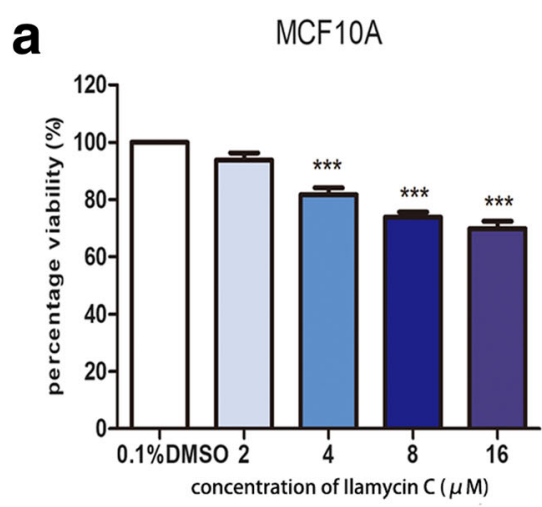

MDA-MB-231

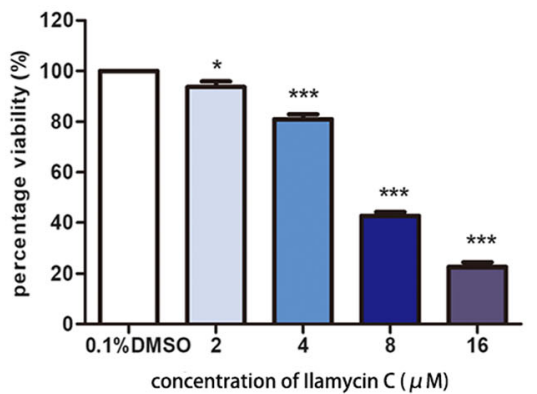

b

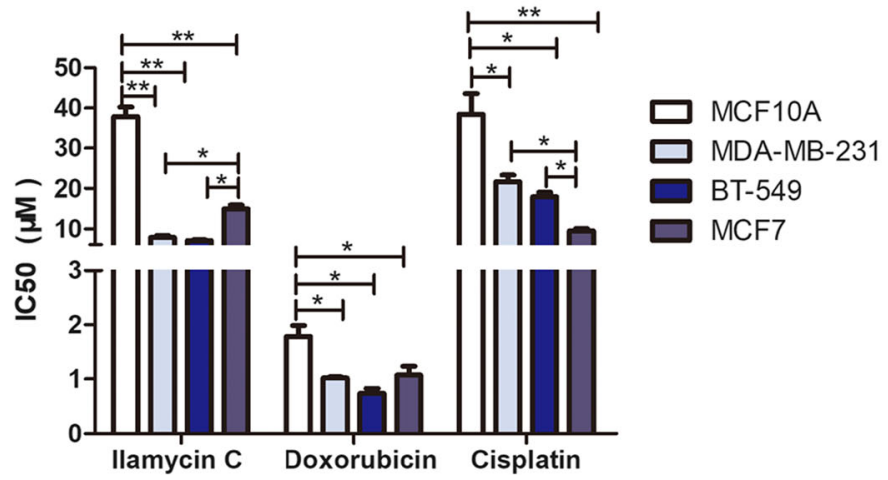

Fig. 1 The cytotoxic activity of llamycin C in breast cancer and nonmalignant cell lines. a The percentages of cell viability with the treatment of increasing concentrations of llamycin $\mathrm{C}$ for $48 \mathrm{~h}$. $\mathbf{b}$ The $\mathrm{IC}_{50}$ values of breast cancer and nonmalignant cell lines with the treatment of llamycin $\mathrm{C}_{\text {, }}$ doxorubicin, and cisplatin for $48 \mathrm{~h}$. Experiments were performed in triplicates. ${ }^{* *} p<0.001,{ }^{* *} p<0.01,{ }^{*} p<0.05$ 
(Beyotime, China). BCA assays were used for protein quantification. Proteins were separated by electrophoresis on a $12 \%$ SDS-polyacrylamide gel, electroblotted onto a PVDF membrane (BioRad Laboratories), and incubated with anti-Bcl-xL, anti-caspase-3, anti-caspase-7, anti-caspase-9, anti-STAT3, anti-vimentin, anti-pSTAT3, anti- $\beta$-actin, anti-Histone H3 (Cell Signaling Technology), anti-Bcl-2, anti-Bax, anti-Fascin (Abcam), anti-PARP1, anti-MMP2, and anti-MMP9 (Proteintech). Immunoreactivity was determined by using a Chemi DOC $^{\mathrm{mm}}$ XRS+ system (BioRad Laboratories).

\section{Statistical analysis}

All data were analyzed by GraphPad Prism 5.0 software. Results are shown as mean \pm SD from three independent experiments. ANOVA and $t$ test were appropriately used. $p<0.05\left(^{*}\right)$ was considered significant.

\section{Results}

Ilamycin C shows a preferential cytotoxic activity against TNBC cells

To investigate whether Ilamycin $\mathrm{C}$ has a better cytotoxic effect on TNBC, the cytotoxic activity of Ilamycin $\mathrm{C}$ was examined using a Cell Counting Kit-8 (CCK-8) assay in two TNBC cell lines (MDA-MB-231 and BT-549), non-TNBC cell line (MCF7), and normal breast epithelial cell line (MCF10A). 0.1\% DMSO was used as vehicle control. As showed in Fig. 1a, the percentages of cell viability in both MDA-MB-231 and BT-549 were sharply reduced compared with MCF7 and MCF10A cells after the treatment of Ilamycin C with increasing concentrations for $48 \mathrm{~h}$, especially at $8 \mu \mathrm{M}$ and $16 \mu \mathrm{M}$. Fifty percent inhibitory concentration $\left(\mathrm{IC}_{50}\right)$ values were calculated to show the cytotoxic activity of Ilamycin $\mathrm{C}$ (Fig. $1 \mathrm{~b}$ ). The $\mathrm{IC}_{50}$ value of MCF7 was $15.93 \mu \mathrm{M}$, and the nonmalignant MCF10A

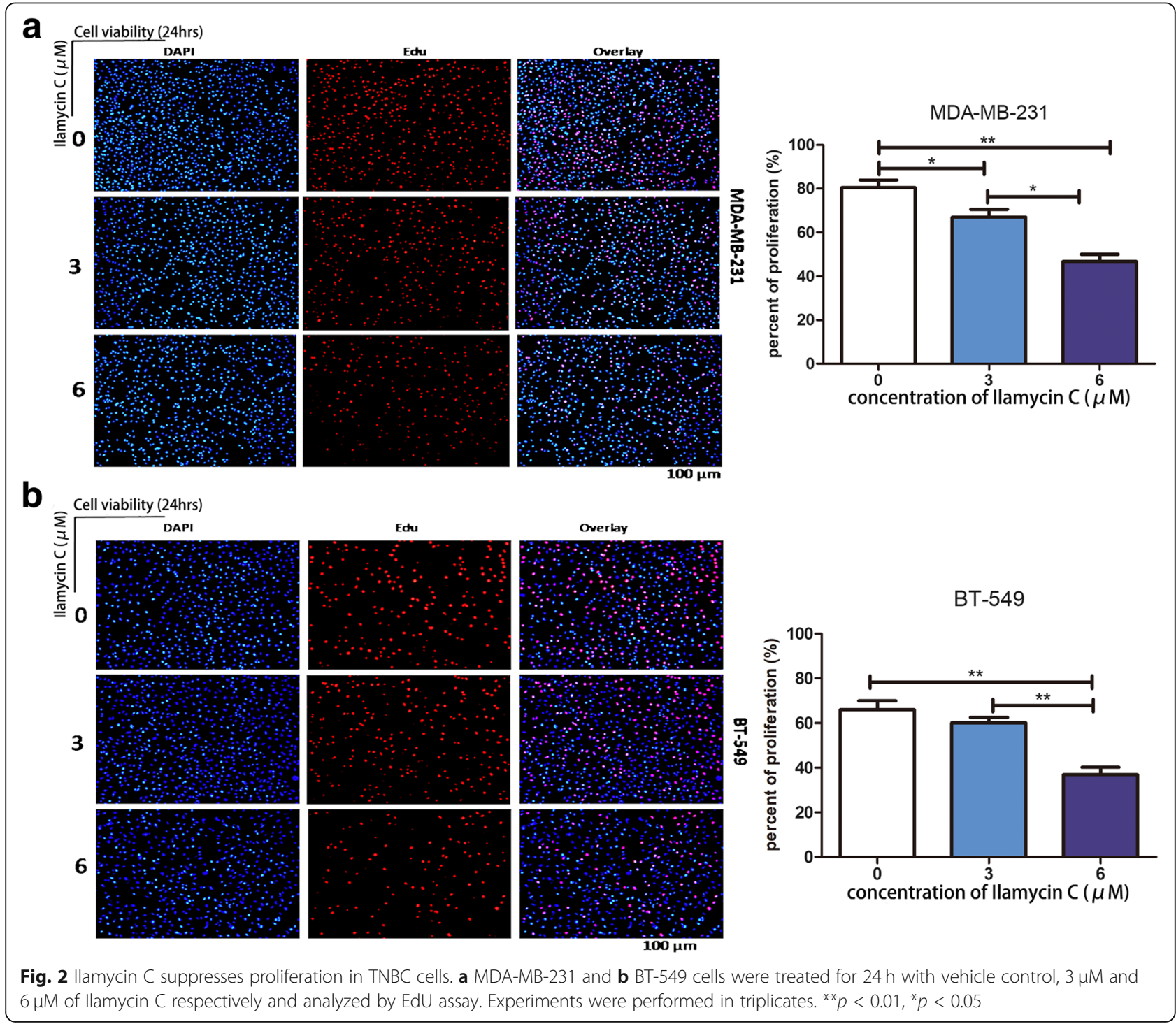


cell line showed an $\mathrm{IC}_{50}$ value of $35.53 \mu \mathrm{M}$. However, the MDA-MB-231 and BT-549 cells exhibited similar mean $\mathrm{IC}_{50}$ values of $7.26 \mu \mathrm{M}$ and $6.91 \mu \mathrm{M}$, respectively. Doxorubicin and cisplatin were used to compare the cytotoxic activity with Ilamycin $\mathrm{C}$. $\mathrm{Th} \mathrm{IC}_{50}$ values showed that doxorubicin had strong cytotoxic activity to normal breast epithelial cell MCF10A and similar cytotoxic activity to both TNBC cells (MDA-MB-231 and BT-549) and non-TNBC cells (MCF7) (Fig. 1b). Cisplatin showed a better cytotoxic activity to MCF7 cells than TNBC cells (Fig. 1b). These results revealed that compared with doxorubicin and cisplatin, Ilamycin $C$ has a better cytotoxic activity against TNBC than non-TNBC MCF7 and nonmalignant MCF10A cells.

\section{Ilamycin C suppresses proliferation in TNBC cells}

Since Ilamycin C decreased TNBC cell viability effectively, we next examined the suppressive effect of Ilamycin $\mathrm{C}$ on TNBC cell proliferation by EdU incorporation assay. MDA-MB-231 and BT-549 cells were treated with different concentrations of Ilamycin $\mathrm{C}$ for $24 \mathrm{~h}$. The results showed that the EdU-positive cells of both cell lines were significantly decreased when treated with Ilamycin $\mathrm{C}$ at $6 \mu \mathrm{M}$, indicating Ilamycin $\mathrm{C}$ can suppress cell proliferation in TNBC (Fig. 2).

\section{Ilamycin C induces apoptosis in TNBC cells}

The effect of Ilamycin C on TNBC apoptosis was further investigated and analyzed by flow cytometry after

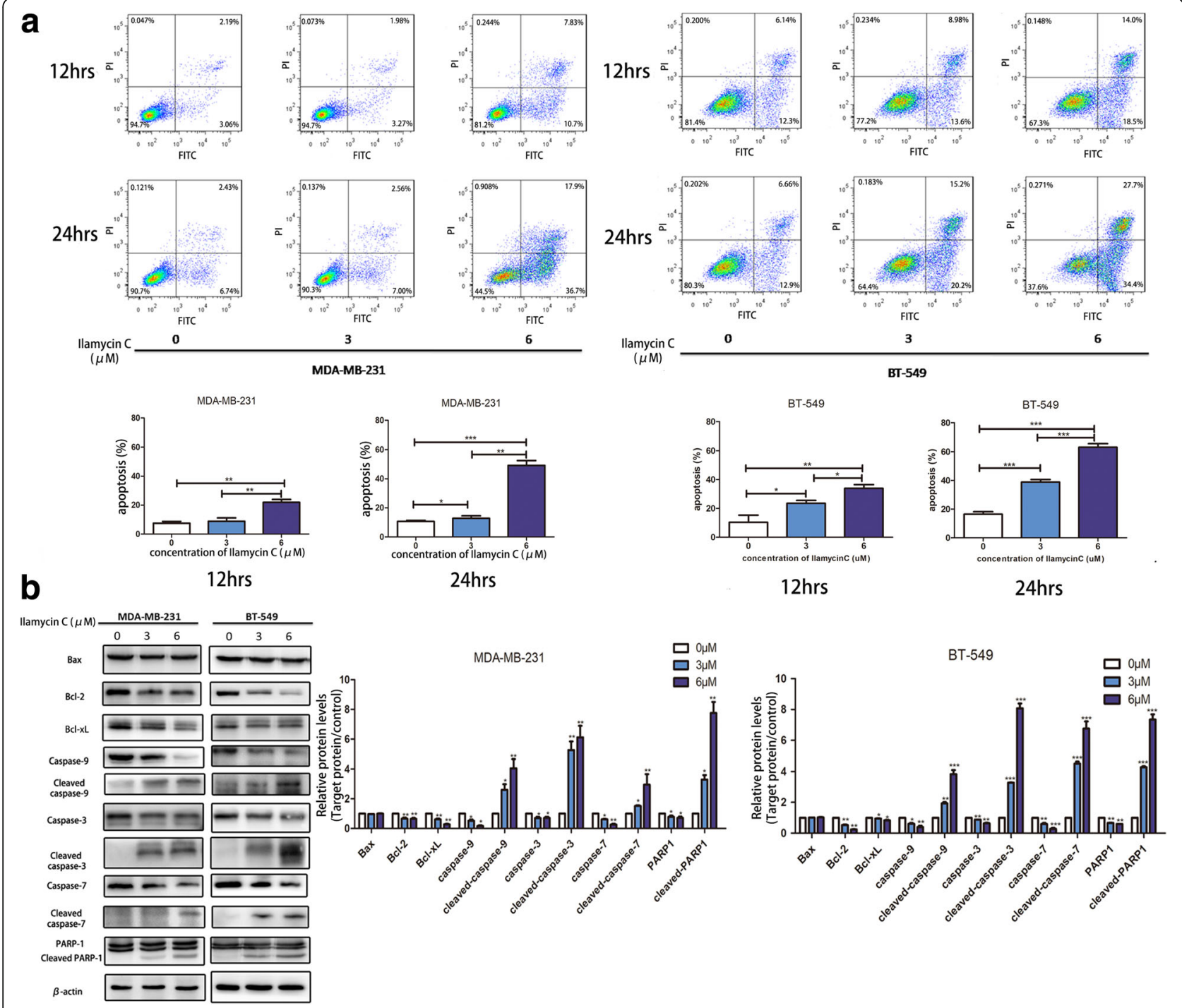

Fig. 3 llamycin C induces apoptosis in TNBC cells. a The percentage of apoptotic cells were analyzed by flow cytometry. $\mathbf{b}$ The expression levels of apoptosis-related proteins were analyzed by western blot. Experiments were performed in triplicates. ${ }^{* * *} p<0.001,{ }^{* *} p<0.01,{ }^{*} p<0.05$ 
treating MDA-MB-231 and BT-549 cells with 0, 3, and $6 \mu \mathrm{M}$ for $12 \mathrm{~h}$ and $24 \mathrm{~h}$. Flow cytometry results demonstrated Ilamycin $C$ induced cell apoptosis, and MDAMB-231 cells showed a significant rise in apoptosis from $5.3 \%$ in vehicle control to $18.5 \%$ at $12 \mathrm{~h}$ and from $9.6 \%$ in vehicle control to $54.6 \%$ at $24 \mathrm{~h}$ when treated with $6 \mu \mathrm{M}$ Ilamycin C. Similar results were gained in BT-549 cells (Fig. 3a).

These findings were confirmed by examining apoptosis-related proteins in MDA-MB-231 and BT-549 cell lines. Anti-apoptotic Bcl-2 families, such as Bcl-xL and $\mathrm{Bcl}-2$, interact with the pore-forming protein Bax to prevent the induction of mitochondrial outer membrane permeabilization (MOMP) and subsequent apoptosis; thus, an increased ratio of $\mathrm{Bax} / \mathrm{Bcl}-2$ signifies the induction of apoptosis in cells [22]. Downregulated antiapoptotic Bcl-2 protein family can activate caspase- 9 and further activate caspase- 3 and caspase- 7 in an intrinsic apoptotic process [23]. PARP1 is an essential apoptotic protein and can be cleaved at the onset of apoptosis by caspase-3 or caspase-7 [24-27]. The western blot results showed that Ilamycin $\mathrm{C}$ increased the levels of cleaved caspase-3,7,9 and PARP1 proteins in both TNBC cell lines, whereas it reduced $\mathrm{Bcl}-2$ and $\mathrm{Bcl}-$ $\mathrm{xL}$ (Fig. 3b). Although Bax was found unaltered in both cell lines when treated with Ilamycin $C$, the increased ratio of Bax/Bcl-2 and accumulation of cleaved caspase-3, 7,9 and PARP1 validated the occurrence of apoptosis in TNBC cells. These results together with flow cytometry data indicated that Ilamycin $C$ can induce apoptosis in TNBC cells partially via $\mathrm{Bax} / \mathrm{Bcl}-2$-related caspasedependent apoptosis pathway.

\section{llamycin C inhibits migration and invasion in TNBC cells}

The fact that TNBC is the most aggressive subtype of breast cancer led us to further explore the effect of Ilamycin $\mathrm{C}$ on migration and invasion in TNBC cells. We utilized transwell migration and Matrigel invasion assays to assess the migratory and invading capacity of MDAMB-231 and BT-549 cell lines following the treatment of Ilamycin $\mathrm{C}$ after $24 \mathrm{~h}$. The migration assay (Fig. $4 \mathrm{a}$ ) demonstrated that the migration abilities of both TNBC cells were significantly weakened in a dose-dependent pattern, especially after the treatment of ilamycin $\mathrm{C}$ at the

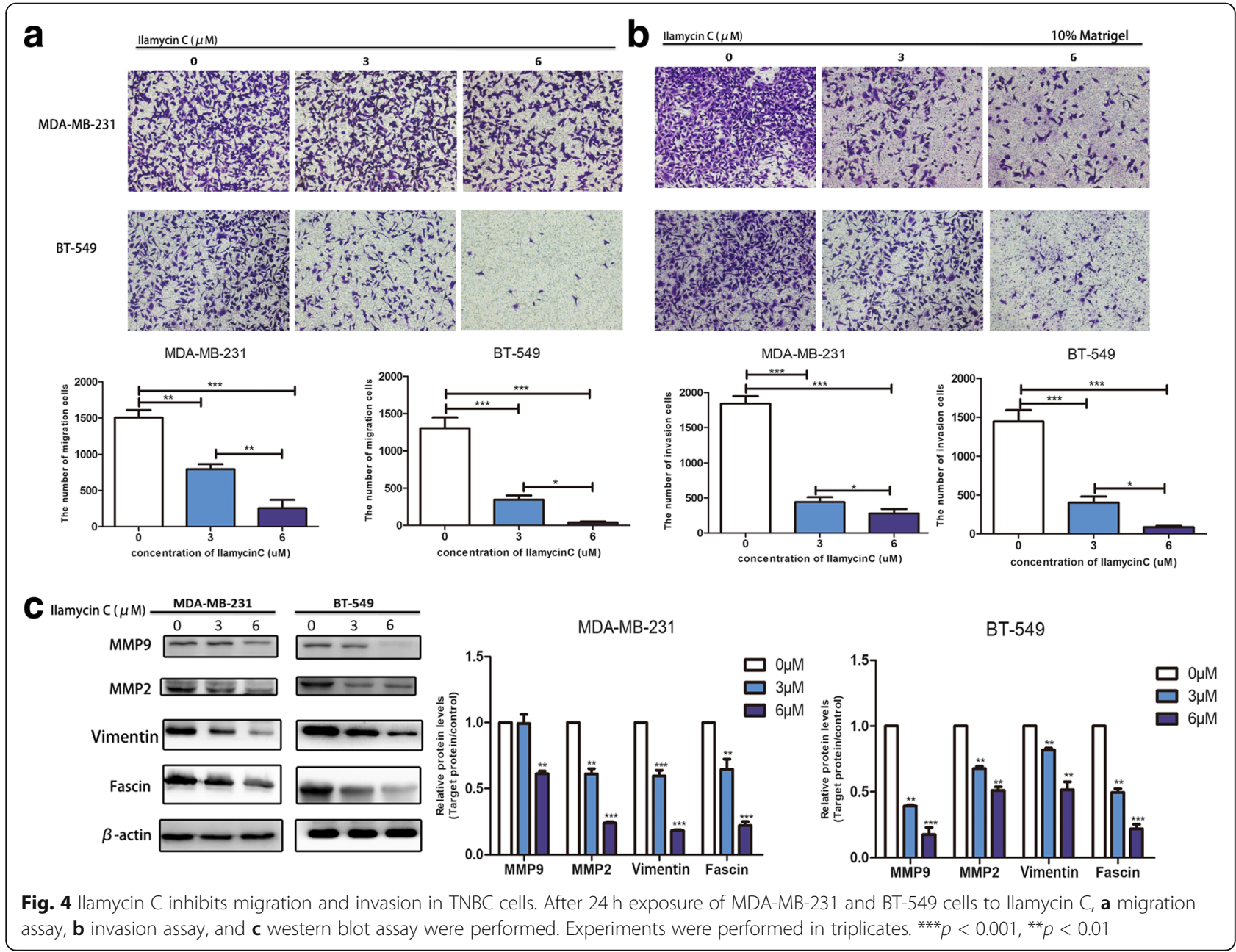


concentration of $6 \mu \mathrm{M}$ compared with the untreated group. For the invasion assay, the significantly reduced number of cells that invaded through Matrigel to the undersurface of transwell filter was observed in both TNBC cell lines when treated with gradually increasing concentration of Ilamycin C (Fig. 4b), demonstrating Ilamycin $C$ could cause a dose-dependent reduction in invasion of both TNBC cells.

Matrix metalloproteinase (MMP) family such as MMP2 and MMP9 [28], the vital epithelial-mesenchymal transition (EMT)-related factor vimentin [29], and the actinbundling protein fascin [30] play essential roles in breast cancer metastasis. Thus, these proteins were detected to further validate the inhibitory effect of Ilamycin $C$ on migration and invasion in TNBC cells using western blot analysis in this study. Results showed that the expressions of MMP2, MMP9, vimentin, and fascin were significantly decreased in the presence of Ilamycin $\mathrm{C}$ treatment in a dose-dependent manner (Fig. 4c). These findings suggested that Ilamycin $\mathrm{C}$ could effectively inhibit invasion and migration through suppressing the levels of MMPs, vimentin, and fascin in TNBC.

\section{Ilamycin C suppresses the IL-6/STAT3 pathway in TNBC cells}

Recent studies showed that activated STAT proteins, especially STAT3, are involved in the progression of many malignant tumors [31]. The suppression of phosphorylated STAT3 (p-STAT3) can induce apoptosis and inhibit metastasis in cancer [32, 33]. In TNBC, poor prognosis and chemotherapy resistance are related to the activation of STAT3 [34]. It has been reported that activated STAT3 was mainly found in TNBC cells [13]. This is consistent with our results that basal p-STAT3 and its upstream protein p-JAK2 were significantly higher in TNBC cells (MDA-MB-231 and BT-549) than nonTNBC cells (MCF7), and undetectable in normal breast cells (MCF10A) (Fig. 5a). We further confirmed that after the exposure to Ilamycin $\mathrm{C}$ for $24 \mathrm{~h}$, the levels of

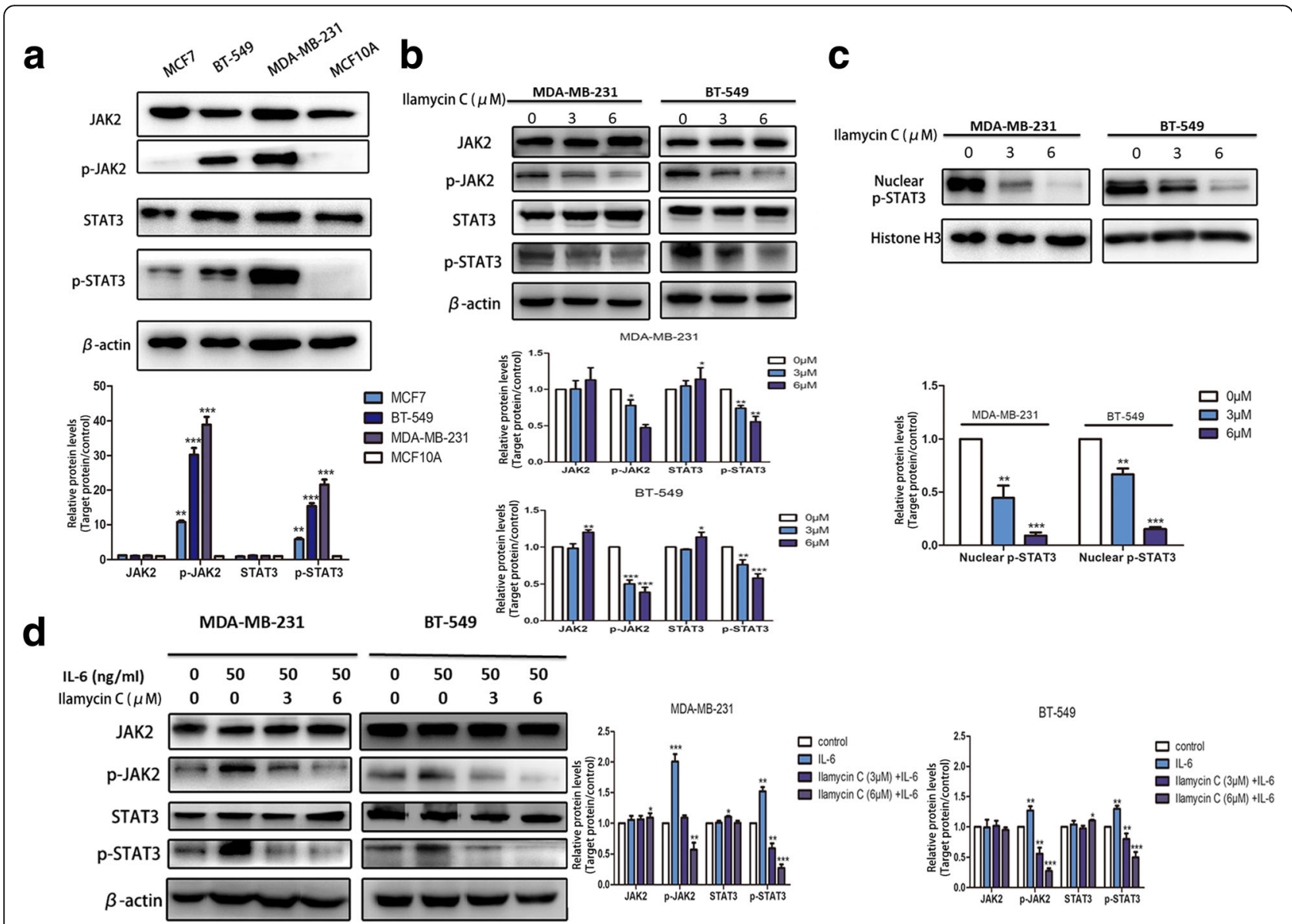

Fig. 5 llamycin C suppresses IL-6/STAT3 pathway in TNBC cells. a The expression of basal p-JAK2 and p-STAT3 in TNBC cell lines (MDA-MB-231, BT-549), non-TNBC cell lines (MCF7), and normal breast cell lines (MCF10A). b The basal p-JAK2 and p-STAT3 were reduced after the treatment of Ilamycin C for $24 \mathrm{~h}$. c Decreased level of p-STAT3 in nucleus after the treatment of llamycin C for $24 \mathrm{~h}$. $\mathbf{d}$ llamycin C prevented IL-6-induced pJAK2 and p-STAT3 in MDA-MB-231 and BT-549 cells after the treatment of llamycin C for $24 \mathrm{~h}$ 
basal p-JAK2 and p-STAT3 were decreased in a dosedependent pattern, whereas the total JAK2 and STAT3 was unaltered in both TNBC cell lines (Fig. 5b).

Studies also demonstrated that only the p-STAT3, rather than STAT3, can translocate to the cell nucleus and play a regulatory role by directly binding to the specific promotor region of targets [35]. To investigate whether Ilamycin C could block the function of p-STAT3 through decreasing the level of p-STAT3 in the nucleus, the level of p-STAT3 in the cell nucleus was examined using extracted nuclear proteins of MDA-MB-231 and BT-549 treated with or without Ilamycin $\mathrm{C}$ for $24 \mathrm{~h}$, and nuclear Histone H3 was used as control. Results showed that Ilamycin $\mathrm{C}$ led to a significant decrease of the p-STAT3 level in the nucleus (Fig. 5c), revealing Ilamycin $C$ could suppress the function of p-STAT3 through decreasing the level of p-STAT3 in the nucleus in TNBC cells.

It has been proved that JAK2/STAT3 can be activated by many upstream proteins including IL-6 [8-10], and the inhibition of IL-6/JAK2/STAT3 signaling activation can suppress the aggressiveness of TNBC [36, 37]. To explore the underlying mechanism of Ilamycin $\mathrm{C}$, we investigated whether Ilamycin $C$ can inhibit IL-6-induced activation of JAK2/STAT3 in TNBC. Cells of MDA-MB231 and BT-549 were pretreated with Ilamycin C in different concentrations for $24 \mathrm{~h}$ before exposing to $50 \mathrm{ng} /$ mL IL-6 for 30 min. As shown in Fig. 5d, IL-6 induced p-JAK2 and p-STAT3 in both TNBC cell lines; however, Ilamycin $C$ can prevent the increase of phosphorylation of the JAK2/STAT3 level. These results revealed that Ilamycin $\mathrm{C}$ may function as a novel inhibitor of the IL-6/ JAK2/STAT3 signaling pathway.

\section{STAT3 overexpression rescues Ilamycin C-mediated effects of apoptosis, migration, and invasion in TNBC}

To investigate whether STAT3 is involved in Ilamycin Cmediated apoptosis, migration, and invasion in TNBC, a lentivirus system was utilized to stably overexpress

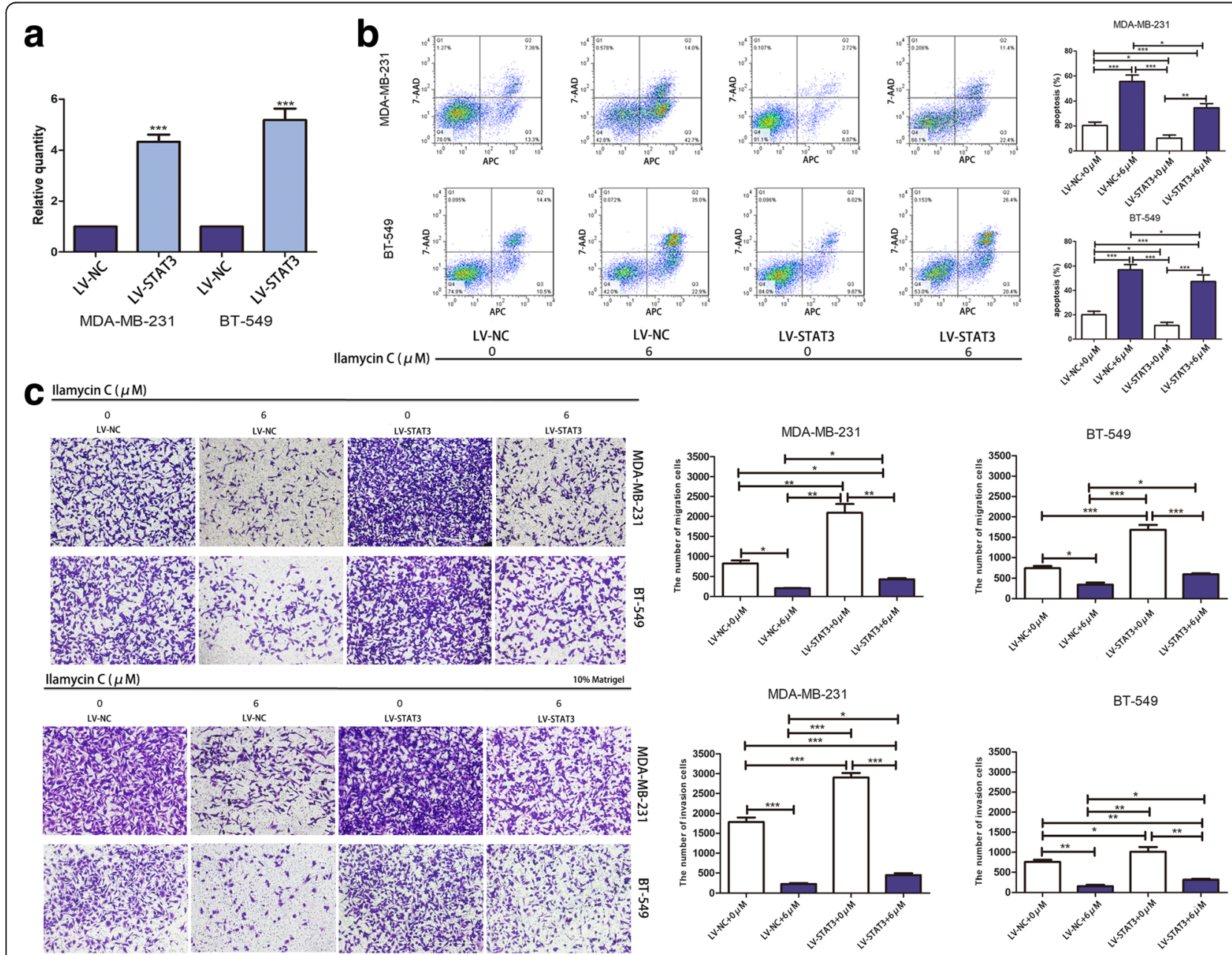

Fig. 6 STAT3 overexpression rescues llamycin C-mediated effects of apoptosis, migration, and invasion in TNBC. a The relative mRNA expression of STAT3 in MDA-MB-231 and BT-549 after the infection with LV-STAT3 or LV-NC by qRT-PCR. b Overexpression of STAT3 reversed Ilamycin Cmediated apoptosis in TNBC cell lines. c Overexpression of STAT3 reversed llamycin C-mediated migration and invasion in TNBC cell lines 
STAT3. Increased STAT3 and p-STAT3 levels were confirmed by qRT-PCR after infecting with lentivirus-STAT3 (LV-STAT3) or lentivirus-negative control (LV-NC) in MDA-MB-231 and BT-549 cell lines (Fig. 6a). Our results showed that Ilamycin $\mathrm{C}$ could sharply promote apoptosis; however, under the same concentration of Ilamycin C, the apoptosis rates of cells overexpressing STAT3 were significantly decreased compared with that of cells infected with LV-NC (Fig. 6b). Similarly, Ilamycin C could suppress migration and invasion by a large margin, but the number of migration and invasion cells was significantly increased in cells overexpressing STAT3 compared with that of cells infected with LV-NC when treated with same concentration of Ilamycin C (Fig. 6c). These results demonstrated that overexpression of STAT3 reversed Ilamycin Cmediated apoptosis, migration, and invasion in TNBC cell lines. The expressions of proteins involved in apoptosis, migration, and invasion, which are downstream targets of p-STAT3, were also confirmed by western blot after infecting with lentivirus-STAT3 (LV-STAT3) or lentivirusnegative control (LV-NC) in MDA-MB-231 and BT-549 cells with or without Ilamycin $\mathrm{C}$ treatment (Fig. 7). These findings indicated that Ilamycin $\mathrm{C}$ exerted its important effects in TNBC through the inhibition of STAT3.

\section{Knockdown of STAT3 enhances llamycin C-mediated} effects of apoptosis, migration, and invasion in TNBC To further determine whether knockdown of STAT3 can enhance Ilamycin C-mediated effects, we transfected
TNBC cells with STAT3 RNA interference (RNAi) to knock down STAT3. The knockdown efficiency of STAT3 was examined in MDA-MB-231 and BT-549 (Fig. 8a). As expected, results showed that knockdown of STAT3 significantly enhanced Ilamycin C-mediated effects of apoptosis, migration, and invasion in TNBC cells (Fig. 8b, c). We also confirmed the expressions of the IL-6/STST3 pathway-related proteins involved in apoptosis, migration, and invasion by western blot after transfecting with si-STAT3 or si-negative control (siNC) in MDA-MB-231 and BT-549 cells with or without Ilamycin $C$ treatment (Fig. 9). These results together with that of STAT3 overexpression provided the evidence that Ilamycin $C$ could induce apoptosis and inhibit migration and invasion by regulating the IL-6/ STAT3 pathway in TNBC.

\section{Discussion}

TNBC is associated with higher metastasis and poorer prognosis compared with other breast cancer subtypes due to the lack of effective chemotherapeutic drugs and frequently acquired chemoresistance [38, 39]. Hence, the development of novel drugs that can selectively and specifically target TNBC cells is urgently needed. In recent years, marine-derived natural products have been found to have better antitumor activities against many kinds of cancer, thus providing a constant source for new drug discovery against cancer [40-42]. Our previous study showed that Ilamycin C, a novel compound separated

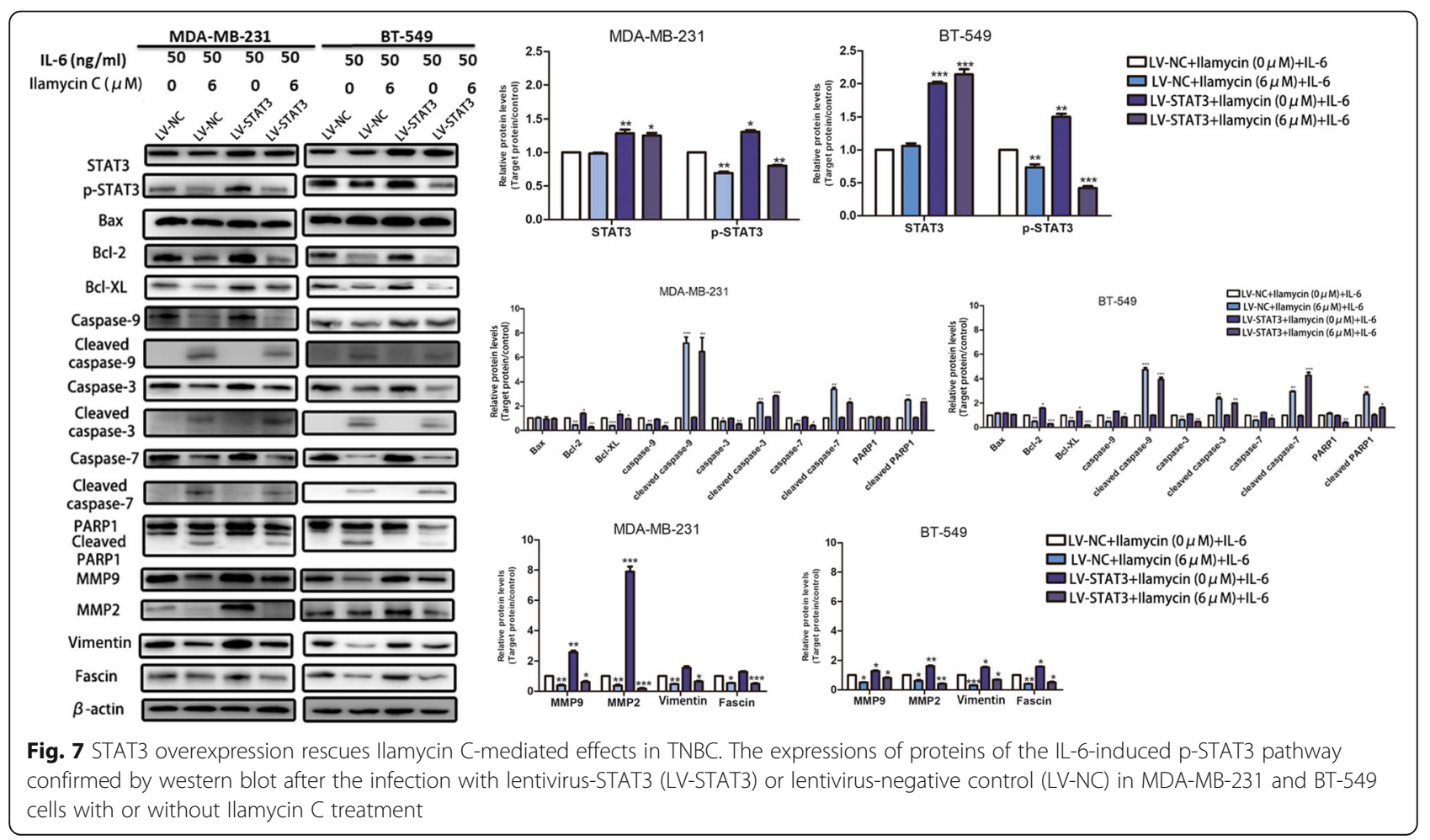




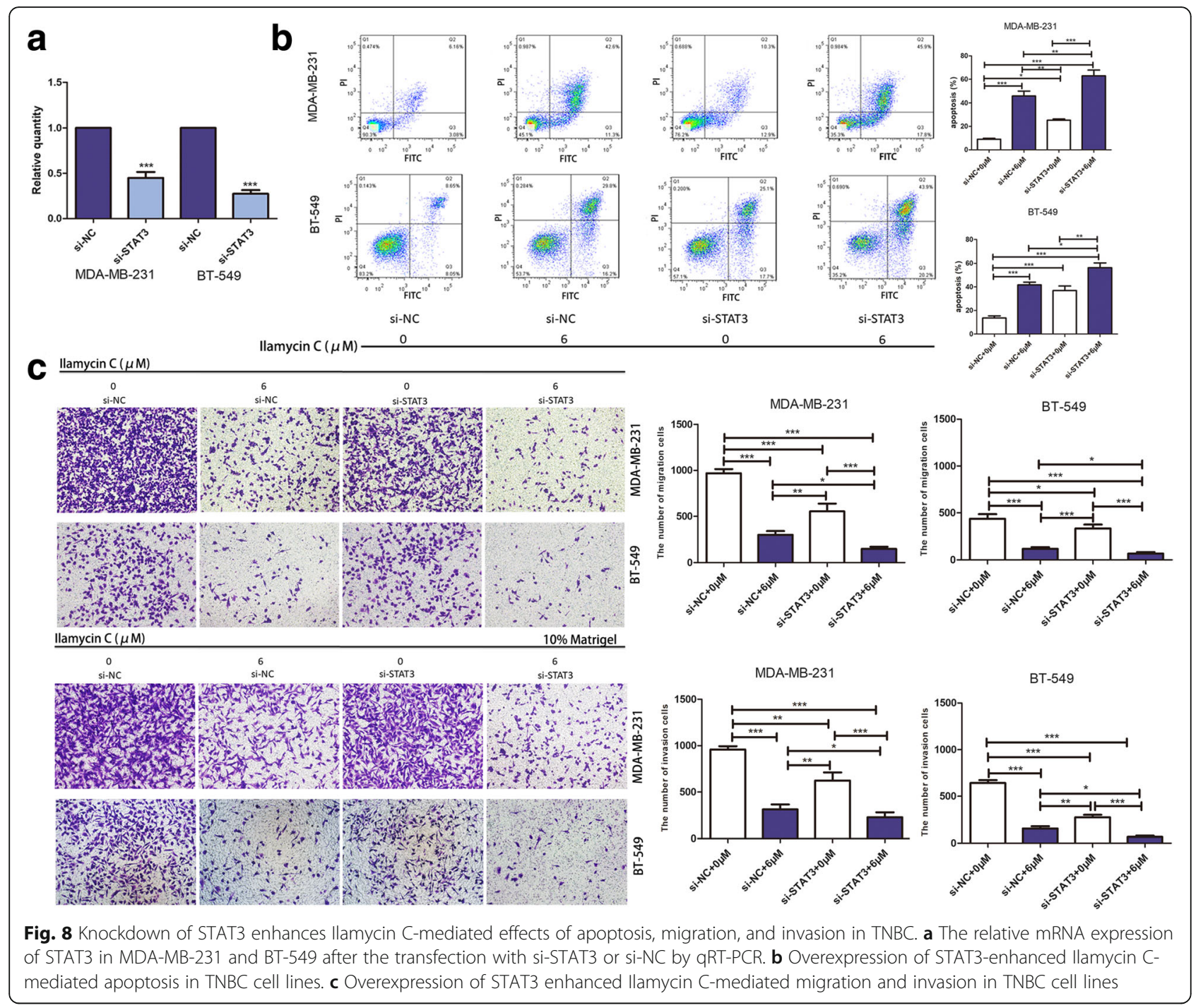

from the deep South China Sea-derived $S$. atratus SCSIO ZH16, has a strong cytotoxic activity against several cancers including breast cancer cell line MCF7 [21]. However, the cytotoxic activity of Ilamycin C in TNBC cells has not yet been tested, and the detailed antitumor mechanism remains unknown. In this work, we tested the cytotoxic activity of Ilamycin C in TNBC cell lines (MDA-MB-231 and BT-549), non-TNBC cell line (MCF7), and normal breast epithelial cell line (MCF10A) . Doxorubicin and cisplatin are the traditional clinical chemotherapy drugs for TNBC [43]. Interestingly, compared with doxorubicin and cisplatin, the $\mathrm{IC}_{50}$ values revealed that the cytotoxic activity of Ilamycin $C$ is more specific to TNBC cells than non-TNBC MCF7 and nonmalignant MCF10A cells, implying Ilamycin $\mathrm{C}$ may play a selective inhibitory role in TNBC, implying Ilamycin C has potential to serve as a novel clinical chemotherapy drug for the treatment of TNBC.
Bcl-2 family members consist of pro-apoptotic and anti-apoptotic proteins, which are crucial to control apoptosis. Besides $\mathrm{Bcl}-2$, the $\mathrm{Bcl}-\mathrm{xL}$, another member of the Bcl-2 family, is known as anti-apoptosis proteins involved in the suppression of caspase activation [23]. Studies also showed that the caspase family is involved in extrinsic and intrinsic apoptotic pathways and caspase- 9 , caspase- 3 , and caspase-7 can be sequentially activated by the $\mathrm{Bcl}-2$ protein family, further cleaving the vital apoptotic protein PARP1 to trigger apoptosis [24-27]. Our results demonstrated that Ilamycin C could significantly promote the apoptosis of TNBC cells at $6 \mu \mathrm{M}$ after the treatment for $12 \mathrm{~h}$ and $24 \mathrm{~h}$ by the decreased interaction of the Bcl-2 family with Bax due to decrease of Bcl-2 and $\mathrm{Bcl}-\mathrm{xL}$ and consequent activation of caspase-3,7,9 and PARP1.

In TNBC patients, poor prognosis is related to the characteristics of strong invasion and migration ability 


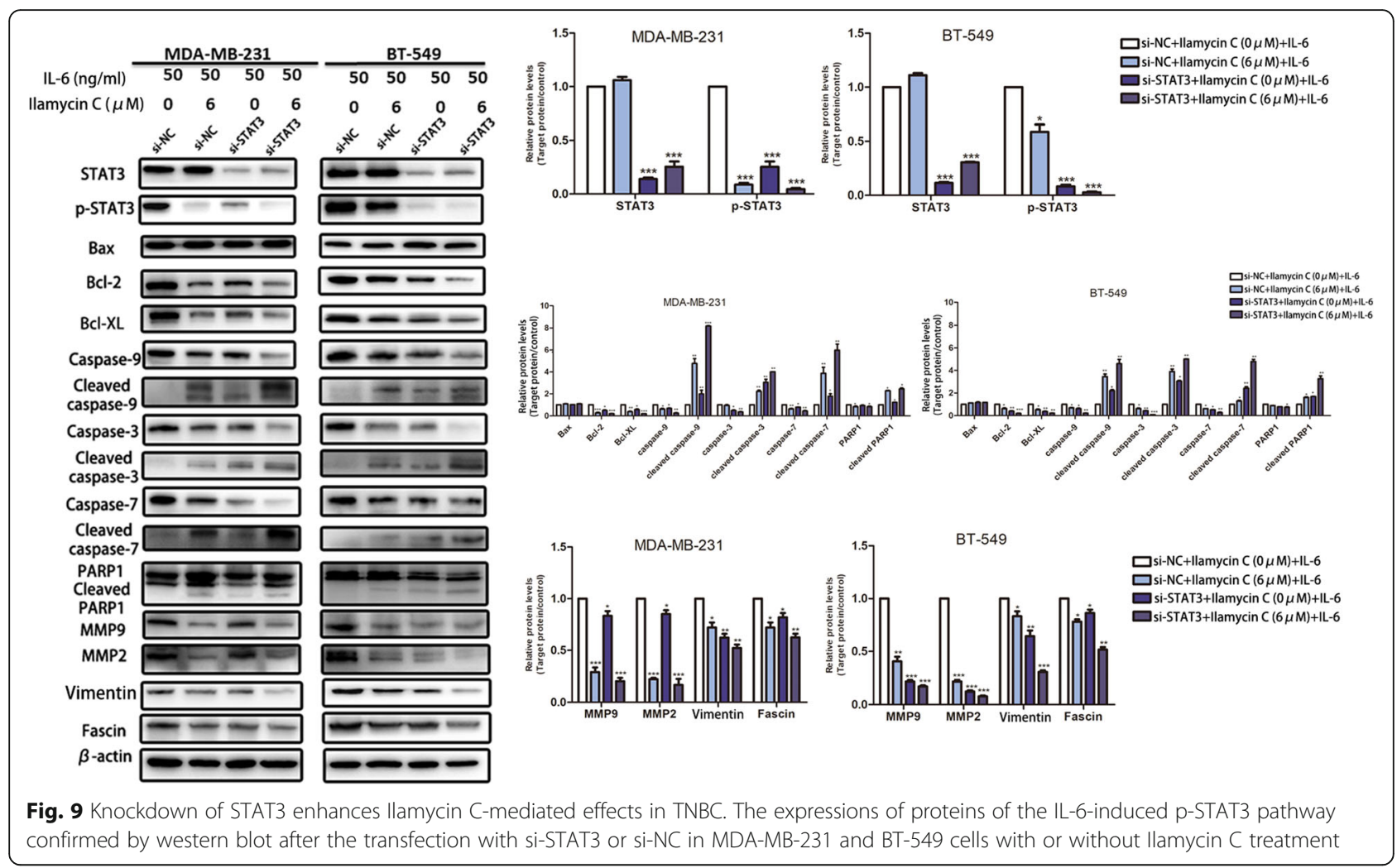

of TNBC cells [44]. We observed that the migration and invasion of MDA-MB-231 and BT-549 cells were suppressed even in the presence of Ilamycin $C$ at $3 \mu \mathrm{M}$ for $24 \mathrm{~h}$. It has been reported that MMPs are major components involved in metastasis, especially, the increased MMP2 and MMP9, two important members of MMPs, are associated with cancer aggressiveness and metastasis in TNBC $[45,46]$. Studies also showed that EMT is an initial step in cancer metastasis, and the major cytoskeletal protein vimentin, which is a positive regulator and a canonical marker of EMT, is correlated with aggressive clinical phenotype in TNBC [47]. Fascin is an actinbundling protein of cytoskeleton, and upregulated fascin can promote migration and invasion in cancer metastasis including TNBC [30]. Our results found that Ilamycin $\mathrm{C}$ reduced the expressions of MMP2, MMP9, vimentin, and fascin in both MDA-MB-231 and BT-549 cell lines, suggesting that Ilamycin $\mathrm{C}$ could inhibit cell invasion and migration through the suppression of MMPs, vimentin, and fascin in TNBC.

Increasing studies showed that STAT3 is an essential gene that participates in cancer cell proliferation, apoptosis, metastasis, and other cellular events including EMT [48-52]. Notably, p-STAT3, activated by JAK2, was found in approximately $80 \%$ of TNBC cells, indicating that STAT3 could be an attractive novel therapeutic target for TNBC [13]. Activated STAT3 dimerizes and translocates to cell nucleus and directly binds to the specific promotor region of targets, such as $\mathrm{Bcl}-2$ families, MMP2, MMP9, vimentin, and fascin leading to transcriptional activation of them [30, 47, 52-54]. Consistent with the reported finding that activated STAT3 was mainly found in TNBC cells [13], our results found that basal p-STAT3 and its upstream protein p-JAK2 were high in TNBC cells (MDA-MB-231 and BT-549), while weak in non-TNBC cells (MCF7) and undetectable in normal breast cells (MCF10A). Moreover, we confirmed Ilamycin $\mathrm{C}$ could block the function of p-STAT3 through decreasing the level of p-STAT3 in the nucleus. STAT3 can be phosphorylated by activated JAK2 induced by IL-6, which is a key mediator of the inflammatory response and functions as a crucial regulator in the progression of breast cancer $[55,56]$. In this study, treatment with Ilamycin $\mathrm{C}$ at $6 \mu \mathrm{M}$ significantly reduced the levels of phosphorylated JAK2 and STAT3 and their downstream proteins involved in apoptosis, migration, and invasion in both MDA-MB-231 and BT-549 cell lines, suggesting that Ilamycin $C$ can function as an effective inhibitor of the IL-6/STAT3 pathway in TNBC cells. Notably, we further validated that STAT3 overexpression could rescue and knockdown of STAT3 could enhance Ilamycin C-mediated effects of apoptosis, migration, and invasion in TNBC. Taken together, these findings provided the evidence that Ilamycin $C$ could induce apoptosis and inhibit migration and invasion by suppressing the IL-6/STAT3 pathway in TNBC. 


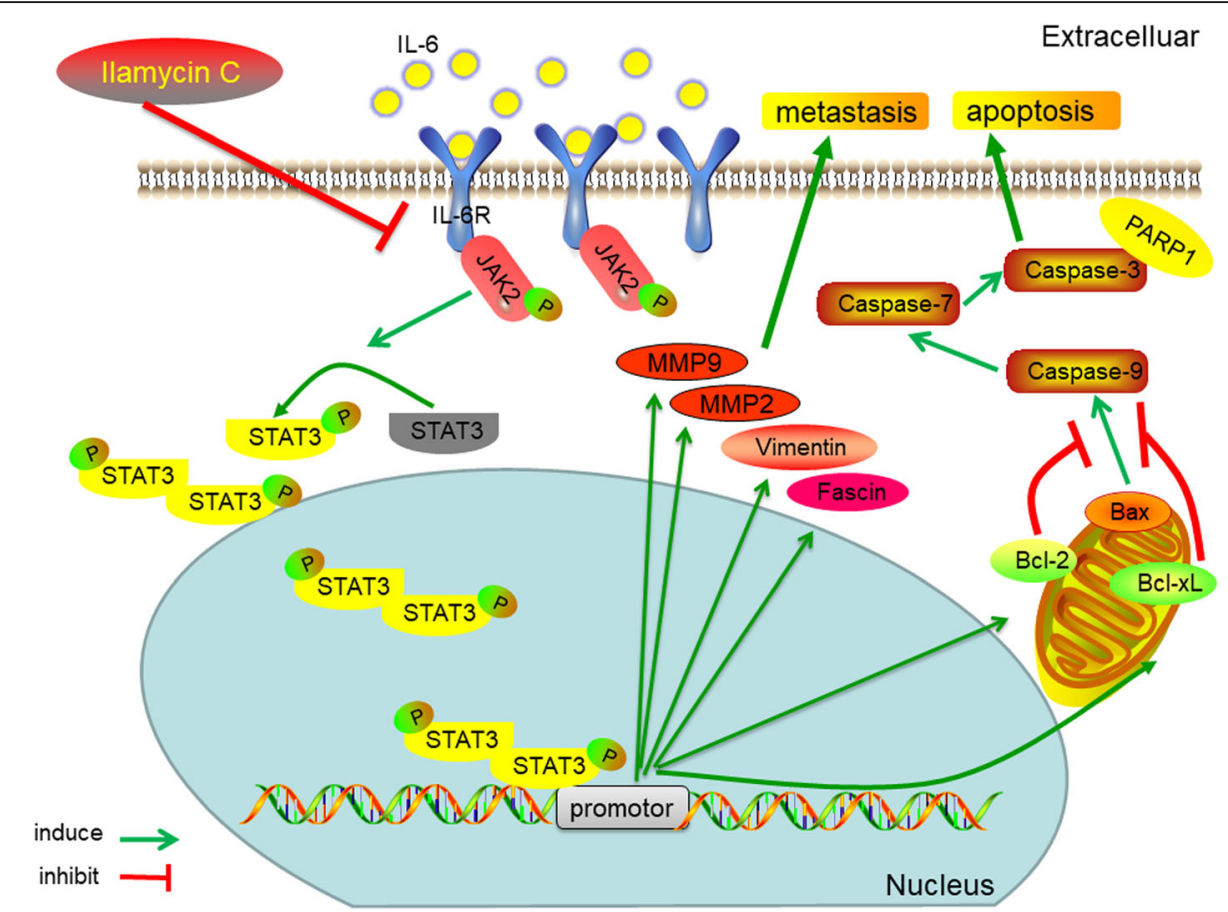

Fig. 10 Schematic presentation of the anti-TNBC mechanism of llamycin C. The inhibition of IL-6 induced JAK2/STAT3 phosphorylation by Ilamycin C abrogates the function of p-STAT3 through decreasing the level of p-STAT3 in the nucleus, thus further regulating the expressions of its downstream target genes, which ultimately contributed to promote Bax/Bcl-2-related caspase-dependent apoptosis and suppress migration and invasion through MMP2/MMP9/vimentin/fascin in TNBC cells

Based on our and reported findings, we propose that the inhibition of IL-6-induced JAK2/STAT3 phosphorylation by Ilamycin $\mathrm{C}$ abrogates the function of p-STAT3 through decreasing the level of p-STAT3 in the nucleus, thus regulating the expressions of its downstream target genes, which ultimately contributed to promote $\mathrm{Bax} / \mathrm{Bcl}-2$-related caspase-dependent apoptosis and suppress migration and invasion through MMP2/MMP9/vimentin/fascin in TNBC cells (Fig. 10). For the aim of developing a novel promising drug candidate for the treatment of TNBC, the in vivo activity of Ilamycin $C$ will be further studied.

\section{Conclusions}

This study found that Ilamycin $C$ has more preferential cytotoxicity in TNBC cells than non-TNBC MCF7 and nonmalignant MCF10A cells. Further investigation revealed the mechanism that Ilamycin $\mathrm{C}$ can induce apoptosis and inhibit invasion and migration in TNBC by suppressing IL-6-induced STAT3 phosphorylation. This study provides the first evidence that Ilamycin $\mathrm{C}$ has the potential as a novel IL-6/STAT3 inhibitor for TNBC treatment in the future.

\section{Additional file}

Additional file 1: Figure S1. Structure of ilamycin C. (TIF $49 \mathrm{~kb})$

\section{Abbreviations}

TNBC: Triple-negative breast cancer; ER: Estrogen receptor; PR: Progesterone receptor; HER2: Human epidermal growth factor receptor 2; STAT3: Signal transducer and activator of transcription-3; MOMP: Mitochondrial outer membrane permeabilization; MMP: Matrix metalloproteinase; EMT: Epithelialmesenchymal transition

\section{Acknowledgements}

Not applicable.

\section{Authors' contributions}

$\mathrm{JJ}, \mathrm{HZ}$, and $\mathrm{JM}$ conceived and designed the experiments. QX and $\mathrm{ZY}$ performed the main experiments and analyzed the data. XH and ZZ participated in cell survival and migration assay. QX, JJ, HZ, and JM wrote the manuscript. All authors read and approved the final manuscript.

\section{Funding}

This work was supported by the National Natural Science Foundation of China (31870046 and 81300398), the Natural Science Foundation of Guangdong Province (2016A030312014, 2018A0303130005 and 2015A03313528), the Special Support Program for Training High-Level Talents in Guangdong (201528018), and Fund of the School of Laboratory Medicine of Guangdong Medical University.

\section{Availability of data and materials}

All authors ensure that all data generated or analyzed during this study are included in this published article.

Ethics approval and consent to participate Not applicable.

Consent for publication Not applicable. 


\section{Competing interests}

The authors declare that they have no competing interests.

Received: 4 March 2019 Accepted: 10 May 2019 Published online: 11 June 2019

\section{References}

1. Han Y, Xie W, Song DG, Powell DJ Jr. Control of triple-negative breast cancer using ex vivo self-enriched, costimulated NKG2D CAR T cells. J Hematol Oncol. 2018;11(1):92.

2. Dent R, Trudeau M, Pritchard Kl, Hanna WM, Kahn HK, Sawka CA, et al. Triple-negative breast cancer: clinical features and patterns of recurrence. Clin Cancer Res. 2007;13(15 Pt 1):4429-34.

3. Haffty BG, Yang Q, Reiss M, Kearney T, Higgins SA, Weidhaas J, et al. Locoregional relapse and distant metastasis in conservatively managed triple negative early-stage breast cancer. J Clin Oncol. 2006;24(36):5652-7.

4. Diana A, Franzese E, Centonze S, Carlino F, Della Corte CM, Ventriglia J, et al. Triple-negative breast cancers: systematic review of the literature on molecular and clinical features with a focus on treatment with innovative drugs. Curr Oncol Rep. 2018;20(10):76.

5. Carey LA, Dees EC, Sawyer L, Gatti L, Moore DT, Collichio F, et al. The triple negative paradox: primary tumor chemosensitivity of breast cancer subtypes. Clin Cancer Res. 2007;13(8):2329-34.

6. Hu X, Huang W, Fan M. Emerging therapies for breast cancer. J Hematol Oncol. 2017:10(1):98.

7. Zhao J, Lin Q, Song Y, Liu D. Universal CARs, universal T cells, and universal CAR T cells. J Hematol Oncol. 2018;11(1):132.

8. Ecker A, Simma O, Hoelbl A, Kenner L, Beug H, Moriggl R, et al. The dark and the bright side of Stat3: proto-oncogene and tumor-suppressor. Front Biosci (Landmark Ed). 2009;(14):2944-58.

9. Puthier D, Bataille R, Amiot M. IL-6 up-regulates mcl-1 in human myeloma cells through JAK / STAT rather than ras / MAP kinase pathway. Eur J Immunol. 1999;29(12):3945-50.

10. Chang $R$, Song $L, X u Y$, Wu Y, Dai C, Wang $X$, et al. Loss of Wwox drives metastasis in triple-negative breast cancer by JAK2/STAT3 axis. Nat Commun. 2018;9(1):3486.

11. Shin SY, Choi JH, Jung E, Gil HN, Lim Y, Lee YH. The EGR1-STAT3 transcription factor axis regulates alpha-melanocyte-stimulating hormone induced tyrosinase gene transcription in melanocytes. J Invest Dermatol. 2019. https://doi.org/10.1016/j.jid.2018.12.020.

12. Liang S, Chen Z, Jiang G, Zhou Y, Liu Q, Su Q, et al. Activation of GPER suppresses migration and angiogenesis of triple negative breast cancer via inhibition of NF-kappaB/L-6 signals. Cancer Lett. 2017;386:12-23.

13. Chun J, Li RJ, Cheng MS, Kim YS. Alantolactone selectively suppresses STAT3 activation and exhibits potent anticancer activity in MDA-MB-231 cells. Cancer Lett. 2015;357(1):393-403.

14. Kang DY, Sp N, Kim DH, Joung YH, Lee HG, Park YM, et al. Salidroside inhibits migration, invasion and angiogenesis of MDA-MB 231 TNBC cells by regulating EGFR/Jak2/STAT3 signaling via MMP2. Int J Oncol. 2018:53(2):877-85.

15. Feng T, Cao W, Shen W, Zhang L, Gu X, Guo Y, et al. Arctigenin inhibits STAT3 and exhibits anticancer potential in human triple-negative breast cancer therapy. Oncotarget. 2017;8(1):329-44.

16. Kim HS, Kim T, Ko H, Lee J, Kim YS, Suh YG. Identification of galiellalactonebased novel STAT3-selective inhibitors with cytotoxic activities against triplenegative breast cancer cell lines. Bioorg Med Chem. 2017;25(19):5032-40.

17. Kim SY, Kang JW, Song X, Kim BK, Yoo YD, Kwon YT, et al. Role of the IL-6JAK1-STAT3-Oct-4 pathway in the conversion of non-stem cancer cells into cancer stem-like cells. Cell Signal. 2013;25(4):961-9.

18. Folmer F, Jaspars M, Schumacher M, Dicato M, Diederich M. Marine natural products targeting phospholipases A2. Biochem Pharmacol. 2010;80(12): 1793-800.

19. Schumacher M, Kelkel M, Dicato M, Diederich M. Gold from the sea: marine compounds as inhibitors of the hallmarks of cancer. Biotechnol Adv. 2011; 29(5):531-47.

20. Martins A, Vieira H, Gaspar H, Santos S. Marketed marine natural products in the pharmaceutical and cosmeceutical industries: tips for success. Mar Drugs. 2014;12(2):1066-101.

21. Ma J, Huang H, Xie Y, Liu Z, Zhao J, Zhang C, et al. Biosynthesis of ilamycins featuring unusual building blocks and engineered production of enhanced anti-tuberculosis agents. Nat Commun. 2017; 8(1):391.

22. Choi HJ, Han JS. Overexpression of phospholipase D enhances BCl-2 expression by activating STAT3 through independent activation of ERK and P38MAPK in HeLa cells. Biochim Biophys Acta. 2012;1823(6): 1082-91.

23. Cheng EH, Kirsch DG, Clem RJ, Ravi R, Kastan MB, Bedi A, et al. Conversion of Bcl-2 to a Bax-like death effector by caspases. Science. 1997;278(5345): 1966-8.

24. Adams JM, Cory S. BCl-2-regulated apoptosis: mechanism and therapeutic potential. Curr Opin Immunol. 2007;19(5):488-96.

25. Thornberry NA, Lazebnik Y. Caspases: enemies within. Science. 1998; 281(5381):1312-6

26. Catlett-Falcone R, Landowski TH, Oshiro MM, Turkson J, Levitzki A, Savino R, et al. Constitutive activation of Stat3 signaling confers resistance to apoptosis in human U266 myeloma cells. Immunity. 1999;10(1):105-15.

27. Hassa PO, Hottiger MO. The diverse biological roles of mammalian PARPS, a small but powerful family of poly-ADP-ribose polymerases. Front Biosci. 2008;13:3046-82.

28. Kessenbrock K, Plaks V, Werb Z. Matrix metalloproteinases: regulators of the tumor microenvironment. Cell. 2010;141(1):52-67.

29. Satelli A, Li S. Vimentin in cancer and its potential as a molecular target for cancer therapy. Cell Mol Life Sci. 2011;68(18):3033-46.

30. Esnakula AK, Ricks-Santi L, Kwagyan J, Kanaan YM, DeWitty RL, Wilson LL, et al. Strong association of fascin expression with triple negative breast cancer and basal-like phenotype in African-American women. J Clin Pathol. 2014;67(2):153-60

31. Carpenter RL, Lo HW. STAT3 target genes relevant to human cancers. Cancers (Basel). 2014;6(2):897-925.

32. Oh E, Kim YJ, An H, Sung D, Cho TM, Farrand $L$, et al. Flubendazole elicits anti-metastatic effects in triple-negative breast cancer via STAT3 inhibition. Int J Cancer. 2018;143(8):1978-93.

33. Li W, Zhang H, Nie M, Tian Y, Chen X, Chen C, et al. Ursolic acid derivative FZU-03,010 inhibits STAT3 and induces cell cycle arrest and apoptosis in renal and breast cancer cells. Acta Biochim Biophys Sin (Shanghai). 2017:49(4):367-73.

34. Thiagarajan PS, Zheng Q, Bhagrath M, Mulkearns-Hubert EE, Myers MG, Lathia JD, et al. STAT3 activation by leptin receptor is essential for TNBC stem cell maintenance. Endocr Relat Cancer. 2017;24(8):415-26.

35. Wu Y, Diab I, Zhang X, Izmailova ES, Zehner ZE. Stat3 enhances vimentin gene expression by binding to the antisilencer element and interacting with the repressor protein, ZBP-89. Oncogene. 2004;23(1):168-78.

36. Liu J, Liu L, Yagüe E, Yang Q, Pan T, Zhao H, et al. GGNBP2 suppresses triple-negative breast cancer aggressiveness through inhibition of IL-6/ STAT3 signaling activation. Breast Cancer Res Treat. 2019;174(1):65-78.

37. Ibrahim SA, Gadalla R, El-Ghonaimy EA, Samir O, Mohamed HT, Hassan $\mathrm{H}$, et al. Syndecan-1 is a novel molecular marker for triple negative inflammatory breast cancer and modulates the cancer stem cell phenotype via the IL-6/STAT3, Notch and EGFR signaling pathways. Mol Cancer. 2017;16(1):57.

38. Huang SP, Liu PY, Kuo CJ, Chen CL, Lee WJ, Tsai YH, et al. The Gah-PLC 1 signaling axis drives metastatic progression in triple-negative breast cancer. J Hematol Oncol. 2017;10(1):114.

39. O'Reilly EA, Gubbins L, Sharma S, Tully R, Guang MH, Weiner-Gorzel K, et al. The fate of chemoresistance in triple negative breast cancer (TNBC). BBA Clin. 2015;3:257-75.

40. Zhang Z, Min X, Huang J, Zhong Y, Wu Y, Li X, et al. Cytoglobosins H and I, new antiproliferative cytochalasans from deep-sea-derived fungus Chaetomium globosum. Mar Drugs. 2016;14(12):pii:E233.

41. Song $Y$, Liu G, Li J, Huang H, Zhang $X$, Zhang $H$, et al. Cytotoxic and antibacterial angucycline- and prodigiosin-analogues from the deep-sea derived Streptomyces sp. SCSIO 11594. Mar Drugs. 2015;13(3):1304-16.

42. Xu X, Zhang X, Nong X, Wang J, Qi S. Brevianamides and mycophenolic acid derivatives from the deep-sea-derived fungus Penicillium brevicompactum DFFSCS025. Mar Drugs. 2017;15(2):pii:E43.

43. WangC KS, Lai X, Cai W, Arfuso F, Sethi G, et al. Triple negative breast cancer in Asia: an insider's view. Cancer Treat Rev. 2018;62:29-38.

44. Chang Q, Bournazou E, Sansone P, Berishaj M, Gao SP, Daly L, et al. The IL6/JAK/Stat3 feed-forward loop drives tumorigenesis and metastasis. Neoplasia. 2013;15(7):848-62. 
45. Kamran MZ, Patil P, Gude RP. Role of STAT3 in cancer metastasis and translational advances. Biomed Res Int. 2013;2013:421821.

46. Shah FD, Shukla SN, Shah PM, Shukla HK, Patel PS. Clinical significance of matrix metalloproteinase 2 and 9 in breast cancer. Indian J Cancer. 2009;46(3):194-202.

47. Yamashita N, Tokunaga E, Kitao H, Hisamatsu Y, Taketani K, Akiyoshi S, et al. Vimentin as a poor prognostic factor for triple-negative breast cancer. J Cancer Res Clin Oncol. 2013;139(5):739-46.

48. Song H, Wang R, Wang S, Lin J. A low-molecular-weight compound discovered through virtual database screening inhibits Stat3 function in breast cancer cells. Proc Natl Acad Sci U S A. 2005;102(13):4700-5.

49. Kortylewski M, Jove R, Yu H. Targeting STAT3 affects melanoma on multiple fronts. Cancer Metastasis Rev. 2005;24(2):315-27.

50. Chen H, Yang Z, Ding C, Chu L, Zhang Y, Terry K, et al. Fragment-based drug design and identification of HJC0123, a novel orally bioavailable STAT3 inhibitor for cancer therapy. Eur J Med Chem. 2013;62:498-507.

51. Wendt MK, Balanis N, Carlin CR, Schiemann WP. STAT3 and epithelialmesenchymal transitions in carcinomas. JAKSTAT. 2014;3(1):e28975.

52. Song Y, Qian L, Song S, Chen L, Zhang Y, Yuan G, et al. Fra-1 and Stat3 synergistically regulate activation of human MMP-9 gene. Mol Immunol. 2008:45(1):137-43.

53. Xie TX, Wei D, Liu M, Gao AC, Ali-Osman F, Sawaya R, et al. Stat3 activation regulates the expression of matrix metalloproteinase-2 and tumor invasion and metastasis. Oncogene. 2004;23(20):3550-60.

54. Dai $X$, Yin C, Zhang Y, Guo G, Zhao C, Wang O, et al. Osthole inhibits triple negative breast cancer cells by suppressing STAT3. J Exp Clin Cancer Res. 2018;37(1):322

55. Dethlefsen C, Hojfeldt G, Hojman P. The role of intratumoral and systemic IL-6 in breast cancer. Breast Cancer Res Treat. 2013;138(3):657-64.

56. Guo Y, Xu F, Lu T, Duan Z, Zhang Z. Interleukin-6 signaling pathway in targeted therapy for cancer. Cancer Treat Rev. 2012;38(7):904-10.

\section{Publisher's Note}

Springer Nature remains neutral with regard to jurisdictional claims in published maps and institutional affiliations.

Ready to submit your research? Choose BMC and benefit from:

- fast, convenient online submission

- thorough peer review by experienced researchers in your field

- rapid publication on acceptance

- support for research data, including large and complex data types

- gold Open Access which fosters wider collaboration and increased citations

- maximum visibility for your research: over $100 \mathrm{M}$ website views per year

At $\mathrm{BMC}$, research is always in progress.

Learn more biomedcentral.com/submissions 